University of Montana

ScholarWorks at University of Montana

Summer 2014

\title{
Industrial Apocalyptic: Neoliberalism, Coal, and the Burlesque
}

\section{Frame}

Jennifer Peeples

Pete Bsumek

Steven J. Schwarze

University of Montana - Missoula, steven.schwarze@umontana.edu

Jen Schneider

Follow this and additional works at: https://scholarworks.umt.edu/communications_pubs Let us know how access to this document benefits you.

\section{Recommended Citation}

Peeples, Jennifer; Bsumek, Pete; Schwarze, Steven J.; and Schneider, Jen, "Industrial Apocalyptic: Neoliberalism, Coal, and the Burlesque Frame" (2014). Communication Studies Faculty Publications. 14. https://scholarworks.umt.edu/communications_pubs/14

This Article is brought to you for free and open access by the Communication Studies at ScholarWorks at University of Montana. It has been accepted for inclusion in Communication Studies Faculty Publications by an authorized administrator of ScholarWorks at University of Montana. For more information, please contact scholarworks@mso.umt.edu. 


\section{INdUSTRIAL APOCALYPTIC: NeOLIBERALISM, COAL, AND THE BURLESQUE FRAME}

\section{Jennifer Peeples, Pete Bsumek, Steve Schwarze, and Jen Schneider}

$<A B S T R A C T>$ Rhetorical scholarship and cultural commentary has demonstrated that environmentalist voices are consistently associated with apocalyptic rhetoric. However, this association deflects attention from the apocalyptic rhetoric that comes from industry and countermovements to environmentalism. This essay seeks to remedy that oversight by proposing the concept of "industrial apocalyptic" as a significant rhetorical form in environmental controversy. Based on analysis of the rhetoric of the US coal industry, we find that these industrial apocalyptic narratives rely on a burlesque frame in order to disrupt the categories of establishment and outsider, and thus thwart environmental regulation. Ultimately, we argue that industrial apocalyptic co-opts environmentalist appeals for radical change in the service of blocking such change and naturalizes neoliberal ideology as the common-sense discourse of the center. $</ A B S T R A C T>$

\section{$<$ AU-INFO $>$}

Jennifer Peeples is Associate Professor in the Department of Languages, Philosophy and Communication Studies at Utah State University, USA; Pete Bsumek is Associate Professor of Communication Studies and Co-Director of Center for Health and Environmental Communication at James Madison University, USA; Steve Schwarze is Associate Professor and Chair in the Department of Communication Studies at The University of Montana, USA; Jen Schneider is Associate Professor of Liberal Arts and International Studies at the Colorado School of Mines, USA. The authors wish to thank Marty Medhurst, the anonymous reviewers, and 
Jonathan Lange for their helpful comments on prior versions of this essay, and thank their families for their ongoing support.

$<K W>$ Keywords: apocalyptic rhetoric; burlesque; coal; environmentalism; industry;

neoliberalism

Word count: 9581 words; 66,242 characters w/spaces

For every concern, I'd invent a crisis; and for every crisis, I'd invent the cause.

--Free Market America, "If I Wanted America to Fail" 1

In the realm of environmental controversy in the United States, apocalyptic rhetoric is consistently associated with environmentalist voices. Examples of such labeling abound: an editorial in the Investor's Business Daily discussing clean air concludes, "Meanwhile, green groups froth with apocalyptic rhetoric."2 Describing a case of ecotage, the editor of the Richmond Times Dispatch claims, "It is mildly tempting to blame mainstream environmentalists, with their sometimes apocalyptic rhetoric, for fostering an atmosphere upon which the lunatic fringe feeds." And in a piece provocatively titled "No reason to fear the environmental bogeyman," Ben Eisen contends, "For decades, the more radical elements of the modern environmental movement have employed terrifying, apocalyptic rhetoric in an effort to scare citizens and policymakers into enacting an agenda that can go beyond common sense environmental policies."4

But the easy association of environmentalism with apocalyptic rhetoric is inaccurate and politically misleading. When mass media identify environmentalism as apocalyptic, they mark environmentalism as radical, outside the mainstream, and unreasonable, which clears a space for 
industry voices to be perceived as the rational center, the common sense approach to environmental issues. ${ }^{5}$ This association also deflects attention from the apocalyptic rhetoric that comes from industry. In his history of environmental politics, Samuel Hays problematizes the association of environmental discourse with the apocalypse, claiming that historically, "environmentalists were the purveyors of optimism about the possibilities of human achievement while administrative and technical leaders were the constant bearers of bad news. In the media the roles were reversed: Environmentalists warned of impending catastrophe, while the technical leadership exuded optimism." 6

Rhetorical scholars who continue to identify apocalyptic rhetoric with environmentalism reinforce this distorted perception of the rhetoric of environmental controversies-a move that unnecessarily limits our understanding of apocalyptic rhetoric. For example, although M. Jimmie Killingsworth and Jacqueline Palmer acknowledge that "the enemies of environmentalism have regularly devised apocalyptic narratives of their own," ${ }^{, 7}$ they also identify apocalyptic narrative as "a standard feature of environmentalist polemic" $"$ and focus primarily on environmentalist voices while giving brief attention to only two examples of apocalyptic rhetoric from opponents of environmentalism: Monsanto's rejoinder to Silent Spring titled The Desolate Year, and the rhetoric of former Interior Secretary James Watt. ${ }^{9}$ More recently, Christina R. Foust and William O. Murphy analyze apocalyptic framing in US press coverage of climate change, yet those frames are almost exclusively built from quotations of pro-environmental sources. ${ }^{10}$ In our view, the scholarly and public focus on environmentalist uses of apocalyptic discourse has deflected attention away from the structure and function of apocalyptic rhetoric used by countermovements to environmentalism. 
This essay seeks to remedy that oversight. We propose the concept of industrial apocalyptic as a significant rhetorical form in environmental controversy, using texts in support of the US coal industry as our examples. We define industrial apocalyptic as narratives that constitute the imminent demise of a particular industry or a broader economic system for the purpose of influencing public opinion and public policy. This form of apocalyptic is consistent with the secular apocalyptic that Kurt Ritter and David Henry identify in the conservative rhetoric of Ronald Reagan, a rhetoric that, in James Arnt Aune's view, consistently seeks to manage the ideological tensions between free market capitalism and patriotism. ${ }^{11}$ We find that the industrial apocalyptic rhetoric used on behalf of the coal industry relies on a burlesque frame to disrupt the categories of establishment and outsider and to thwart environmental regulation. ${ }^{12}$ Ultimately, the industrial apocalyptic co-opts environmentalist appeals for radical change in the service of blocking such change and naturalizes neoliberal ideology as the common-sense discourse of the center.

The essay proceeds by first reviewing scholarship on apocalyptic rhetoric and the burlesque frame to establish our theoretical framework. Then, it justifies our focus on the rhetoric supporting the coal industry before analyzing the apocalyptic and burlesque dimensions of that rhetoric. The latter portion of the essay draws out several implications that advance our understanding of those concepts as well as the role that industrial apocalyptic rhetoric plays in articulating neoliberal hegemony.

\section{Theorizing Apocalyptic Rhetoric}

Apocalyptic rhetoric is a recurring feature of American public discourse that has drawn the attention of many rhetorical scholars. ${ }^{13}$ Foust and Murphy define apocalyptic rhetoric as 
having "a linear temporality emphasizing a catastrophic end-point that is more or less outside the purview of human agency," with stronger versions exhibiting a "persistent placement of 'natural' events as catastrophic, inevitable, and outside of 'human' control."14 Apocalyptic rhetoric functions as a predictive discourse which aids the audience in understanding the past, present, and future, ${ }^{15}$ and as an ideological discourse in which the narrator promotes a "change in consciousness or political agenda" that is as extreme as the predicted catastrophe. ${ }^{16}$ Scholars have noted that apocalyptic rhetoric in particular has enjoyed a resurgence in popularity in contemporary times, in and beyond environmental discourse. ${ }^{17}$ Apocalyptic appeals are an increasingly pervasive cultural phenomenon, perhaps brought on by "millennial apocalypticism," or the widespread sense that the turn of the century would be marked by apocalyptic change. ${ }^{18}$ We see this as additional evidence that attributing apocalyptic appeals solely to environmentalists is itself a rhetorical move, one that deflects attention from industrial apocalyptic rhetoric.

Environmentalist versions of apocalyptic rhetoric have garnered mostly unfavorable attention precisely because they challenge one of the primary touchstones of US culture: progress. ${ }^{19}$ The impacts of economic and industrial progress became a concern in the $1950 \mathrm{~s}$ as people began to see the environmental downsides of advances that had been touted as lifeimproving. ${ }^{20}$ In the following decade, Rachel Carson's 1962 book Silent Spring and Paul R. Ehrlich's 1968 The Population Bomb were widely read, popular books which narrated a dark future if people did not control the use of pesticides and human reproduction, with Ehrlich causing considerable controversy with his dire claims that it was already too late to prevent a substantial increase in the world death rate. ${ }^{21}$ Climate change has reawakened overt public questioning of progress, although Killingsworth and Palmer maintain that the public response to 
climate change has produced a weaker version of apocalyptic rhetoric — not the imminent collapse of human society with no means of intervention, but one that allows behavioral changes to help mitigate the effects of global warming. ${ }^{22}$

Scholars with an interest in environmentalist apocalyptic also have attempted to theorize the effects of apocalyptic rhetoric on environmental action. They query, does apocalyptic rhetoric effectively engage an audience and create a sense of environmental identity or responsibility? ${ }^{23}$ Or does it backfire, generating fear and alienating the audience into a state of denial or withdrawal? ${ }^{24}$ In their analysis of the apocalyptic "flood myth" in the global warming feature film The Day After Tomorrow, Michael Salvador and Todd Norton argue that the apocalyptic appeal can do either or both, depending on how it is framed: "Contemporary apocalyptic and jeremiad discourses of humans-in-nature manifest a palpable dialectic that sustains human agency as both subject to the power of nature and effectual at intervening in nature. ${ }^{25}$ Yet, these authors argue, that dialectic can be dissolved, emphasizing agency or not, depending on the framing of the appeal.

The framing of apocalyptic discourse has been taken up most thoroughly by Foust and Murphy. Using Stephen O'Leary’s ${ }^{26}$ classification of apocalyptic discourse into Burkean frames, Foust and Murphy find in their examination of US press coverage of global warming both "a tragic apocalypse, which constitutes global warming as a matter of cosmic Fate; and a comic apocalypse, which suggests that mistaken humans have a capacity to influence (within limits) the end of the global warming narrative. ${ }^{27}$ They contend that the tragic approach forces readers to choose sides between the global warming naysayers and the apocalyptical environmentalists, concluding that it is "untenable as a rhetorical strategy for encouraging the public to become active participants in climate change mitigation. ${ }^{, 28}$ They offer the comic apocalyptic frame as a 
potential solution to the dilemma of human agency. "The comic frame promotes humanity as mistaken, rather than evil. ... To the extent that humanity is mistaken, it has agency for making different choices which may lead to different outcomes. ... Humanity is less likely to be resigned to its fate, and, as such, may be inspired to take steps to change."29

In the following sections, we expand this discussion of apocalyptic rhetoric in two significant ways. First, we extend the application of Burkean frames to apocalyptic rhetoric by defining a burlesque variant of that discourse. Second, we analyze an industrial version of apocalyptic rhetoric, describing its central features and explaining how it functions dialectically to counter and weaken environmental claims.

\section{The Burlesque Frame}

Rhetorical analyses of the burlesque frame proceed from Kenneth Burke's designation of burlesque as a frame of rejection in which an advocate ridicules opponents mercilessly and “deliberately suppresses any consideration of the 'mitigating circumstances' that would put his subject in a better light." ${ }^{, 30}$ As Mark Moore maintains, "The burlesque frame, with polemical style, conveys attitudes of superiority and rejection from a narrow perspective designed primarily for caricature and debunking. ... The burlesque frame of reference divides controversial issues and problems into what Burke describes as black-and-white, all-or-nothing schemas, hence the emphasis on polemic." ${ }^{31}$ Burlesque depicts the scene in terms of "an environment of gross and categorical violation of traditional principles;",32 it seizes on the external actions of opponents and "drive[s] them to absurd extremes," 33 and it "invites not sympathy but scoffing dismissal" of those opponents. ${ }^{34}$ A. Cheree Carlson concurs that in the burlesque frame there is no possibility 
for identification with the object of ridicule, since doing so would only tarnish the virtue of the audience. $^{35}$

The burlesque frame has been identified in diverse forms of environmental rhetoric, including public controversies over natural resource management, political cartoons, and television shows. ${ }^{36}$ However, no studies have explicitly linked burlesque to apocalyptic rhetoric; Moore only implicitly connects burlesque to apocalyptic when he explains that the rights-based, all-or-nothing burlesque rhetoric of water wars in the Western United States has resulted in "a doomsday discourse of rights lost by a particular group. ${ }^{37}$ A similar pattern can be observed in the rhetoric of the coal industry, revealing how the extremes of the burlesque frame can lend themselves to the elaboration of an apocalyptic narrative.

We use the scholarship on burlesque to identify a form of apocalyptic rhetoric that differs from the comic and tragic apocalyptic frames described by Foust and Murphy, and to explain the functions and implications of that rhetoric as it is employed by the coal industry to naturalize neoliberal ideology and thwart environmental regulation. First, we observe that the burlesque frame retains capacity for human agency in contrast to the tragic frame; however, that action is one of rejection. Chris Smith and Ben Voth compare the comic and burlesque frames in this way: "Action in the comic frame provides a platform to confront and correct problems while simultaneously laughing at faults instead of persecuting individuals for wrongs committed.... When acceptance of the 'comic fool' does not occur, the emphasis shifts to rejection and the dramaturgical frame becomes burlesque. ${ }^{, 38}$ Likewise, Edward Appel places burlesque on a continuum halfway between comic-reformist rhetoric at one pole and tragedy at the other pole. "Instead of the crimes and evils of tragedy or the mere mistakes and impediments of comedy, the scene in burlesque is fraught with gross violations of revered, traditional principles of life and 
action. ${ }^{„ 39}$ In turn, burlesque typically promotes a limited form of scapegoating of one's adversaries, advocating exclusion from the public sphere rather than complete tragic destruction. ${ }^{40}$ Burlesque thus offers a form of agency in response to apocalyptic conditions, but one that looks quite different from the more charitable comic corrective championed by Foust and Murphy.

Moreover, burlesque allows us to further elaborate the particular character of the coal industry's anti-environmental rhetoric and its resonances with contemporary conservatism and a broader neoliberal ideology. It is notable that Appel explains burlesque in relation to two titans of conservatism in the United States, William F. Buckley and Rush Limbaugh. He claims that the polemical caricature and scapegoating of burlesque rhetoric leads to a redemptive vision rooted in narrow, sectarian, "cynical self-interest." ${ }^{, 41}$ Indeed, Appel's study of Limbaugh concludes by explaining how the talk show host's distinctive rhetoric, a "burlesque tinged with tragedy," was a fitting rhetorical articulation within the context and purposes of the conservative movement's ascendancy in the mid 1990s—-specifically, "free-market economics, low taxes, and repeal of all repressive federal laws that stood in the way of personal enterprise and aggrandizement." ${ }^{, 42}$ These are precisely the issues that have animated the neoliberal ideology undergirding US conservatism since the mid-1970s. In Robert J. Antonio and Robert J. Brulle's account, neoliberalism is grounded in a free-market ideology that calls for "deregulation, privatization, welfare cuts, and reduced taxation to revive high corporate profits and economic growth. ${ }^{, 43}$ Moreover, they claim that neoliberalism gained political traction with Reagan's appointment of James Watt and that "anti-environmentalism has been, from the start, a keystone of neoliberal antiregulatory politics. ${ }^{44}$ Thus, it is important to observe how the burlesque frame helps to sustain that ideology and its particular form of anti-environmentalism. 


\section{Coal: An Industry Under Pressure}

We focus on the coal industry for a number of reasons. First, for decades coal has dominated electricity production in the United States, providing half of electricity consumed. In the spring of 2012 that total share dropped to below $40 \%$ for the first time and may continue falling. ${ }^{45}$ The industry is under pressure from several directions - environmental regulation due to climate change, negative public opinion over the practice of mountaintop removal mining, the growing concern over coal-fired power plants, and, perhaps most notably, market competition from natural gas. The coal industry unquestionably sees itself, or at least has represented itself, as facing catastrophe. ${ }^{46}$ Second, the rhetorical choices the industry makes in response to these conditions are a significant contributor to the discourse of economic crisis that has been circulating since 2008. These choices are telling in terms of the industry's ideology, its understanding of its audience, and how it views its relationship to local communities and the national economy. Third, we cannot ignore the financial resources of energy companies and how that enhances the circulation of their rhetoric. For example, the New York Times calculated that two months before the 2012 presidential election, "estimated spending on television ads promoting coal and more oil and gas drilling or criticizing clean energy [had] exceeded $\$ 153$ million" for " 138 ads on energy issues broadcast . . by the presidential campaigns, political parties, energy companies, trade associations and third-party spenders. ${ }^{, 47}$ The coal mining industry made $\$ 13.4$ million in federal campaign contributions during the 2012 election cycle

and since 2010 has averaged $\$ 18$ million in spending on corporate lobbying. ${ }^{48}$ Finally, and most significant for this project, aside from a few studies of major oil companies like Exxon ${ }^{49}$ and 
$\mathrm{BP},{ }^{50}$ little research in rhetorical studies has examined public discourse surrounding conventional energy extraction, making it an important area of study for the discipline.

In order to understand the rhetorical dynamics of apocalyptic narrative and the burlesque frame, we gathered coal advertisements and other industry-supporting texts, including Greenpeace's archive of coal ads from 1921 to $2012^{51}$ and videos and print ads from two industry-supported campaigns, the FACES (Federation for American Coal, Energy and Security)

of Coal and America's Power. ${ }^{52}$ In order to examine the widespread use of the burlesque apocalyptic frame, we also collected popular press and op-ed pieces produced by allied organizations and think tanks that support the coal industry. We then compared and contrasted the environmental apocalyptic appeals found by Foust and Murphy to the industrial apocalyptic appeals found in the coal texts. This approach allowed us to focus on defining and delineating the structure and function of industrial apocalyptic rhetoric.

\section{Killing Coal}

Even a cursory glance at the advertisements and promotional materials of the coal industry makes it clear that the industry views the United States in general, and the coal mining regions in particular, as imperiled. The sonorous voice narrating one FACES television advertisement intones: "Coal provides nearly $50 \%$ of our nation's electricity and keeps our electricity affordable. But now coal is threatened by EPA regulations that would shut off access to American coal, put tens of thousands of Americans out of work, and could cause electric rates to triple. Keep the lights on. ${ }^{, 53}$ The fundamental premise of this argument is that regulations not only threaten the coal industry but also put America on the brink of energy and economic ruin: the industrial apocalypse. 
An ad from the FACES of coal website provides a more detailed version of this apocalyptic scenario. The header, constructed to look like a green road sign one might see crossing a state border, reads: "Welcome to West Virginia!" In caution-yellow font written diagonally across the welcome are the words, "A federal no-job zone by the order of the Environmental Protection Agency." The text below reads, "America's jobless rate is stuck at $10 \%$, yet unelected bureaucrats in our own federal government are making things worse! The U.S. EPA's latest attack on coal mining threatens to make economic dead zones of vast areas of West Virginia, Kentucky, Virginia, Pennsylvania, Tennessee and Ohio. It may wipe out thousands of jobs in Appalachia—potentially yours.” Billboards supplementing the campaign show the six states highlighted in red with a large banner of the same color that reads "Obama's NO JOB ZONE." The yard signs, also in red and black, proclaim: "STOP the WAR on COAL. FIRE OBAMA.”

We found a consistent combination of apocalyptic narrative and the burlesque frame in the texts we analyzed. This rhetoric establishes that:

- There is an imminent disaster (economic dead zone, American failure, control of the United States by foreign governments, destruction of the economy, loss of liberty, coming tyranny).

- There is an entity to blame for the disaster (federal government, the EPA, unelected bureaucrats, Obama, environmental movement).

- The entity is illogical, inept, hypocritical, devious, and malicious.

- The entity is beyond redemption and therefore must be opposed or removed.

- The audience is in no way responsible for the impending disaster. 
These elements receive an even more hyperbolic treatment in an ad from the organization Kansans for Affordable Energy. ${ }^{54}$ Under prominent headshots of Vladimir Putin, Hugo Chavez, and Mahmoud Ahmadinejad, the red-lettered title asks "Why are These Men Smiling?" The answer reads: "Because the recent decision by the Sebelius administration [Kathleen Sebelius, then-Governor of Kansas] means that Kansas will import more natural gas from countries like Russia, Venezuela, and Iran." The organization then claims that this action will cause higher electric bills, lost economic activity, and reduced energy security, thus allowing "hostile foreign countries to control the energy policy of Kansas and America." The solution is to call the Kansas House of Representatives, letting them know that the "state's electricity must come from clean, affordable, reliable coal-America's energy future." The ad was published in response to Kansas Department of Health and Environment Secretary Rod Bremby denying air-quality permits necessary for an existing coal fire power plant to expand. In his decision, Bremby cited "the ever-increasing environmental risks associated with the emitted carbon dioxide."55 Sebelius upheld the decision. $^{56}$

The advertisement sets up an apocalyptic vision of a nation whose economy and energy are controlled by its political enemies. The cause of this dire situation is not widespread reliance on fossil fuels or high levels of individual consumption, but the decision made by Governor Sebelius's administration. Her capacity to make decisions is presented as flawed to the point that her actions solely benefit America's enemies and put the nation at risk. The organization does not encourage the viewer to contact Sebelius, but other (seemingly more reasonable) state legislators-Sebelius is symbolically cast out. The ad clearly illustrates the burlesque frame as it presents a simplified and polarized argument crafted for easy dismissal. Sebelius is stripped of her title and position. She and her administration are characterized solely in pejorative terms. 
The text implies rejection in that no attempt is made to understand her reasoning or negotiate with her administration. She is defective beyond repair.

Industry campaigns are not the only examples of this rhetorical form. We found conservative pundits, talk radio hosts, and authors of popular non-fiction texts also supporting industry using apocalyptic rhetoric in a burlesque frame. Recent books by conservative syndicated radio hosts Mark Levin (Liberty and Tyranny, 2009) and Brian Sussman (EcoTyranny: How the Left's Green Agenda Will Dismantle America, 2012) provide prime examples of industrial apocalyptic. ${ }^{57}$ These most recent examples of industrial apocalypse link traditional anti-environmental arguments about the economic disasters that will result from environmental policies and regulations to contemporary iterations of threats to individual liberty and impending tyranny that will result from environmental regulations. In doing so, they represent a rearticulation of the secular apocalyptic that Ritter and Henry associate with Ronald Reagan, and illustrate the way in which contemporary versions of the industrial apocalyptic are attempting to manage ideological tensions. ${ }^{58}$ Consider, for example, Levin's description of the impact of a "cap and trade" policy to curb the impacts of global warming:

The coming invasion of the home and the workplace, the restriction of individual liberty, independence, and mobility, and the deconstruction of America's economic system and impoverishing of the citizenry are justified in the name of a long and growing roster of preposterous assertions [about the impact of global warming]. ${ }^{59}$

This argumentative strategy couples climate change denial rhetoric with neoliberal concerns about "big government," the destruction of the free market system, and the loss of individual freedom. All are combined into an apocalyptic vision of the future. Environmental advocates, 
especially climate change advocates, are labeled and demonized as "alarmists," "statists," or “enviro-statists.” They are not simply mistaken, but malicious and callous.

A common feature of these industrial apocalyptics is the re-telling of the historical narrative and implications of Rachel Carson's Silent Spring, a canonical environmental text that raised awareness in the United States of the threat of pesticides for human and environmental health. In Levin's retelling, Carson, “the EPA and its environmental group masters conspired in a deliberate and systematic distortion of science, leading to genocide-like numbers of deaths of human beings throughout the underdeveloped world." ${ }^{60}$ DDT is praised as a "wonder chemical" that protected American soldiers from malaria, and is now maliciously withheld from people in the "undeveloped world." Environmentalists are assigned tyrannical power, and associated with genocide. The burlesque apocalyptic framing of environmentalists could not be clearer-if they are responsible for genocide, then they are beyond redemption.

This attempt to revive the controversy associated with Carson's Silent Spring represents a return to the apocalyptic roots of anti-environmental rhetoric in Monsanto's The Desolate Year. The resonances between the latter text and contemporary industrial apocalyptic rhetoric are numerous. As in The Desolate Year, contemporary opponents of environmentalism generate apocalyptic visions of economic collapse, as environmentalist policies create "dead zones" and resource constraints that set prices spiraling out of control. Likewise, there are allusions to "the looming threat of some insidious other lurking beyond U.S. borders" who threatens sovereignty. ${ }^{61}$ Finally, The Desolate Year's narrative ends by posing a question that articulates apocalyptic anxieties in nationalist terms similar to those in Levin's and Sussman's books: "What, at the end of such a year, would be the fate of the United States of America?"62 
However, the contemporary version of industrial apocalyptic deviates from The Desolate Year in at least one important respect: its explicit identification and strident characterization of environmentalists and regulators as blameworthy entities. In The Desolate Year, environmental and public health regulation still have a role; the Food and Drug Administration and Department of Agriculture are simply prevented from doing their job effectively without the needed tool of pesticides. ${ }^{63}$ But more recent instances of industrial apocalyptic are animated by a full-throated attack on the environmental-regulatory complex, pushing this rhetoric more fully into a burlesque frame. As such, this anti-regulatory attack is also an attack on the environmental progress of the twentieth century; that progress and the broader environmental agenda is recast as a threat to the free market and the values that support it. Consequently, we interpret the resonances between coal industry ads and conservative punditry as emblematic of a broader neoliberal ideology.

\section{Wanting America To Fail}

An exemplary instance of industrial apocalyptic that reinforces neoliberalism is the fiveminute video "If I Wanted America to Fail" that was posted on both the FACES and Friends of Coal (a related industry front group) websites during the spring of 2012. The video was originally produced by Free Market America, a public relations campaign supported by Americans for Limited Government, a nonprofit group that supports and organizes state ballot initiatives that are strongly neoliberal and anti-regulatory. ${ }^{64}$ The video features a charismatic actor filmed against a black background, eloquently moving through a series of talking points, speaking directly to the camera. Suspenseful and cinematic instrumental music plays in the background. His face is lit by a high key light, and the talking points are strung together with a series of jump cuts, or cutaways to iconographic American images such as the Washington 
Monument, the American flag, and medium shots of working- and middle-class Americans. But the video also features images that represent industrialized American society: extraction machinery, sleek airports, and city streets.

The talking points are just that - a string of statements that obliquely reference actual events but are not logically or explicitly connected to one another. Rather than offer an internally coherent argument, they signal the viewer to particular ideological platforms and hot-button controversies (such as the spotted owl conflict in the American Northwest) and link them together only through the repeated refrain of "If I wanted America to fail." The video opens with this depiction:

If I wanted America to fail ... I would start with energy. I'd cut off America's supply of cheap, abundant energy. I couldn't take it by force. So, I'd make Americans feel guilty for using the energy that heats their homes, fuels their cars, runs their businesses, and powers their economy. I'd make cheap energy expensive, so that expensive energy would seem cheap. I would empower unelected bureaucrats to all-but-outlaw America's most abundant sources of energy. And after banning its use in America, I'd make it illegal for American companies to ship it overseas.

As the speaker vilifies the "unelected bureaucrats," we see images of a pencil scribbling across a page, and then the camera pans over stacks of books, perhaps meant to symbolize the intellectual, elitist left. Although the entire video seems to be ideologically aligned with the rhetoric of the coal industry, it is this point about regulation that makes the video so appealing to the coal lobby, whose primary political and economic concern is the regulation of carbon emissions. The "America Fail" video amplifies these concerns, suggesting that such regulation is part of an unpatriotic scheme to take down the country. The metonymic twinning of "coal" 
and "America" is the coal industry's most frequent and powerful rhetorical move, and one that fits the burlesque frame perfectly: any attempt by bureaucrats to regulate coal must be seen as a threat to America.

The repeated refrain of "If I wanted America to fail" facilitates a rhetorical strategy of amplification. Much like the enumeration of harms caused by pests in The Desolate Year, the video compiles a series of ways to make America "fail" that include teaching children about the global warming conspiracy, demonizing prosperity, over-regulating small business, ridiculing energy executives, saving spotted owls, and "fixing" free markets with schemes such as carbon cap and trade. Echoing concerns about over-regulation, and again reifying the concern over government officials, the speaker contends, "I would empower unaccountable bureaucracies seated in a distant capital to bully Americans out of their dreams and their property rights. I'd send federal agents to raid guitar factories for using the wrong kind of wood; I'd force homeowners to tear down the homes they built on their own land." From here the speaker makes explicit who is responsible for putting America at risk. "If I wanted America to fail, I would transform the environmental agenda from a document of conservation to an economic suicide pact. I would concede entire industries to our economic rivals by imposing regulations that cost trillions." The themes of economic catastrophe or apocalypse associated with environmental policy and regulation are thus reiterated.

The speaker then elaborates on the maliciousness and depravity of those who want America to fail, stating, "I would celebrate those who preach environmental austerity in public, while indulging in lavish lifestyles in private." This statement illustrates supposed environmentalist hypocrisy and is visually accompanied by the clicking of champagne glasses and then by headlines that reference Al Gore and pop singer Madonna. The speaker drives home 
the burlesque frame by stating: "I would prey on the goodness and decency of ordinary Americans. I would only need to convince them, that all of this, is for the greater good." In doing so, the video positions the audience, "ordinary Americans" as the victims of hypocritical environmentalists who "prey" upon them. The speaker concludes with the words, "If I wanted America to fail, I suppose I wouldn't change a thing."

Across all these examples, the means of avoiding the apocalypse are both explicit and implicit. The explicit appeals are for the audience to call their representatives, vote, join organizations such as FACES or America's Power, and/or support the coal industry. The other, often implicit, solution is to remove the categorically flawed entity that has caused or exacerbated the oncoming apocalypse. Unlike the comic frame in which the entity is shown to have a redeemable flaw, in the burlesque frame the person or organization is beyond recovery and thus must be removed. Public calls to stop Obama's reelection, for his impeachment, the dismantling of the EPA, or the dismissal of various elected officials, while not necessarily stated in each advertisement, are the logical, if extreme, response to the burlesque version of industrial apocalyptic.

\section{Strategic and Ideological Implications of Industrial Apocalyptic Rhetoric}

Given the ongoing rhetorical struggle over the meaning of environmental and economic crises, our analysis of industrial apocalyptic in the rhetoric of the coal industry provides an example of "how crises get rearticulated and transformed as they circulate among various contexts. ${ }^{\circ 65}$ In this instance, industrial apocalyptic helps the coal industry respond to a variety of pressures and recast environmental regulation as the cause of economic crisis that poses a fundamental threat to individual liberty. In this concluding section, we use our analysis to 
address two critical questions about industrial apocalyptic rhetoric and its influence on broader trends in public discourse. First, why is there such a consistent, strong backlash to environmental apocalyptic rhetoric and such a muted response to the industrial apocalyptic rejoinder? Even though opposing sides warn of approaching catastrophe, the industrial rejoinder seems to generate far less public resistance. Second, how does industrial apocalyptic rhetoric contribute to the hegemony of neoliberalism, which sustains existing patterns of resource extraction, production, and consumption? Both questions are crucial for interpreting and criticizing the public discourse that constitutes controversies over energy resources and environmental protection.

\section{Environmental versus Industrial Apocalyptic}

In comparing environmental apocalyptic rhetoric to its industrial counterpart, environmental apocalyptic rhetoric asks more of its audience. It constructs a problem that is not isolated or contained; it affects everyone and calls into question each aspect of a person's life. As a result, the apocalyptic rhetoric used by environmentalists often calls for a "fully radical transformation of society" ${ }^{96}$ and a fundamental ideological shift. ${ }^{67}$ It takes control of the problem out of human hands (tragic frame) or lessens the human agency to stop the apocalypse (comic frame). ${ }^{68}$ Environmental apocalyptic rhetoric implies difficult fixes-systemic and expensive changes to infrastructures and cultures, and its speakers get chided when they provide solutions that do not seem to match the magnitude of the problem, such as changing a light bulb.

In contrast, industrial apocalyptic rhetoric asks less of the audience: it merely encourages its audience to support the countermovement, join an organization, or vote. It constructs a problem that is significant but contained; it is regional, organizational, individual or industry- 
specific. Like other instances of secular apocalyptic rhetoric, industrial apocalyptic "treats historical events as contingent on human action;," ${ }^{\prime 9}$ it puts both the problem and solution squarely in human hands. Moreover, it provides quick fixes, offering small changes via a comic frame or calling for removal of the offending entity through the burlesque.

The shift in human agency may be one of the reasons that the response to the environmental apocalyptic rhetoric varies so dramatically from the industrial. Environmental rhetoric often frames the apocalypse as unintended: individual decisions about the chemicals people put on their lawns, the modes of transportation they use, and the number of children they will have contribute to an impending disaster that no one person has caused, yet all are responsible for. The burlesque version of industrial apocalyptic flips this argument through the use of a scapegoat, thus absolving the audience of any responsibility for imminent catastrophe. This scapegoat is powerful, often to the point of tyranny. Whereas environmentalists place individual decision making at the root of the apocalypse, the industrial rejoinder claims that the true catastrophe is over-regulation of individual decisions, which poses a fundamental threat to the free market. The focus on an all-controlling tyrant absolves the audience of any personal guilt for the problem, thereby removing the impetus to lash out at the rhetor. Instead, they are called upon to funnel their anger toward a scapegoat in order to again regain control of their lives. Following the logic of the burlesque frame, the scapegoat must then be rejected.

This explanation of why industrial apocalyptic rhetoric finds easier public acceptance must also take into consideration how the burlesque frame promotes broader ideological goals. Moore explains the scapegoating dynamics of burlesque by arguing that "This act of rejection also implies some corresponding acceptance of something else, thus the tendency toward extreme partisanship.. ${ }^{, 70}$ But what, exactly, does apocalyptic rhetoric ask its audience to accept? 
The answer is often vague. For environmentalists, ambiguity about goals leaves them vulnerable to charges that they are idealistic, lacking a clear vision of the future and a practical blueprint for getting there. ${ }^{71}$ In contrast, for industry, burlesque apocalyptic functions as a negative method of promoting acceptance of the status quo. By casting blame on a caricatured environmentalist position and then offering rejection of that position as the preferred solution, the coal industry can deflect sustained critical attention to the environmental consequences of extracting and burning coal. Instead of a "radical transformation of society," industrial apocalyptic calls for the buttressing of traditional free-market principles.

\section{Industrial Apocalyptic, Burlesque, and Neoliberalism}

Three of the rhetorical elements of burlesque described previously illustrate how industrial apocalyptic amplifies and normalizes neoliberal ideals. First, burlesque depicts the scene of action as "an environment of gross and categorical violation of traditional principles.",72 Second, it "drives external actions of opponents to absurd extremes."73 Third, it "invites not sympathy but scoffing dismissal., ${ }^{, 74}$ By exploring the way that the coal industry's rhetoric integrates these moves with the apocalyptic narrative form, we can see how neoliberal ideals are amplified and normalized by industrial apocalyptic.

First, neoliberal ideology is articulated through burlesque by framing the scene as a gross and categorical violation of traditional free-market principles. Each of the texts we analyze emphasizes ideographs such as $<$ liberty $>$, $<$ free markets $>$, and $<$ private property $>$. The identification of traditional principles grounds the industrial apocalyptic narratives in neoliberal ideology. Further, identifying and focusing on the counterpoints, or threats to these traditional principles_-“environmental regulation," "unelected bureaucrats," “environmentalists”—reframes environmental concerns and other pressures on industry as evidence of a threat to cherished 
economic and cultural principles that undergird neoliberalism. In addition, the Kansans for Affordable Energy ad emphasizes the ideograph of $<$ security $>$ as it raises the specter of "hostile foreign countries" trying to control US energy policy, articulating a link between neoliberal economic ideology and neoconservative national security rhetoric. Market regulation not only infringes on individual liberty, it also puts national sovereignty at risk.

Second, as the coal industry uses the burlesque to caricature opponents and their actions by pushing them to absurd extremes, it deflects attention from neoliberal practices and allows those practices to escape critical scrutiny. For example, the ad that focuses on a "no job zone" shifts emphasis away from corporate profits to unemployed individuals, and attributes unemployment to the "war on coal" launched by Obama and "unelected bureaucrats." This buttresses the neoliberal ideology by implicitly defining individuals as reliant on industry and by providing the industry with a scapegoat that shifts responsibility for unemployment away from production-side measures utilized to increased corporate efficiency (such as mountaintop removal mining and increased mechanization), and market competition from other energy sources such as natural gas.

Third, the scoffing dismissal of burlesque is ultimately a reactionary rhetoric designed to thwart progressive challenges to the neoliberal status quo. Consider the last line of the "If I wanted American Fail" video: "If I wanted America to fail, I suppose I wouldn't change a thing." Here we see the "appearance" of a call for radical change, a sort of call to arms to resist and rebel against a caricatured foe-environmentalists and government agencies. With this move the coal industry attempts to hold back a challenge to their hegemony by reversing the roles traditionally played in environmental controversies ${ }^{75}$ - environmentalists are cast as all-powerful tyrants of the establishment, the coal industry as a rebellious, persecuted underdog. The ideographs in play 
are familiar neoliberal fare (liberty, freedom, private property) and are designed to tap into the spirit of American rebellion and revolution. In short, the burlesque apocalyptic becomes an expansive rhetoric (from "no job zone" to American Failure) that goes on the offensive to resist change.

Further, the industrial apocalyptic as deployed by the coal industry illustrates the complexity of contemporary rhetorics of reaction. Albert O. Hirschman, in his classic study, identifies three argumentative forms associated with the rhetoric of reaction - the perversity thesis, the futility thesis, and the jeopardy thesis. ${ }^{76}$ The industrial apocalyptic presents a sophisticated variant of the jeopardy thesis, in which proposed progressive reforms are constituted as a threat to previously hard-won gains associated with liberty and economic security. For the jeopardy thesis to be effective, Hirschman argues, "there must exist the living memory of the highly prized earlier victory."77 And yet, living memories are rhetorically produced. By building narratives that articulate gross violations of traditional principles, provide scapegoats for declining economic conditions, and offer rebellion against environmental tyrants, the industrial apocalyptic does the rhetorical work needed to produce the living memory that enables the rhetorical form.

The apocalyptic narrative form brings together all these elements of reaction in a burlesque form as it shapes an audience's understanding of past, present and future. ${ }^{78}$ This seamless narrative depicts an ideal past of full employment in which historic conflicts between labor and industry are ignored; a present in which scapegoats are responsible for declining production and increasing unemployment; and a future in which imagined economic catastrophe and tyranny will prove the claims of the coal industry once and for all. ${ }^{79}$ Indeed, the coal industry is able to use cost cutting strategies, such as laying-off workers, to "prove" that this 
future is in fact a reality. ${ }^{80}$ However, the backward-looking call for restoration of traditional free-market principles is a temporal shift that enables this rhetoric to avoid the apocalyptic label. Thus, by taking advantage of the apocalyptic narrative form the coal industry is able to amplify its burlesque frame and hide its apocalyptic claims in plain sight.

The apocalyptic rhetoric and the burlesque framing deployed by the coal industry also enable the industrial position to be seen as the common-sense discourse of the center. As Star Muir explains, the very assertion that environmentalists engage in apocalyptic rhetoric and the absence of a countervailing label for similar industry rhetoric does the rhetorical work of positioning environmentalism as extreme and its proposed solutions as hopelessly utopian. ${ }^{81}$ Moreover, as Hays suggests, labeling environmentalists as doomsayers elides the optimism that comes with the belief that environmental problems can be identified and solved, and deflects attention from the inherent pessimism of industrial apocalyptic discourse, which asserts that any attempt at addressing environmental problems will lead to certain economic decline and job loss. ${ }^{82}$ That pessimism is reconstituted as commonsensical and realistic.

Our analysis extends Hays's insight by developing the ideological implications of these rhetorical strategies; in particular, that industrial apocalyptic in a burlesque frame provides a rhetorical form that is well suited to normalizing neoliberalism as common sense. It is effective for two main reasons. First, liberalism, and by extension neoliberalism, are ideologies that are often articulated through a burlesque frame. As Burke notes, "The method of burlesque (polemic, caricature) is partial not only in the sense of partisan, but also in the sense of incompleteness. ${ }^{, 83}$ Liberalism, according to Burke, offers rights, but denies obligations. It defends liberty and private property in absolutist terms, and ignores corresponding and complementary duties to society and the common good, which, in turn, would "require us to stress the ambivalence of 
rights and obligations." ${ }^{84}$ For Burke, "the very basis of classic liberal apologetics, the overemphasis upon freedom, was but a sober way of carrying out the burlesque genius." ${ }^{95}$ Neoliberalism, like liberalism, utilizes this same kind of over-emphasis on freedom to craft an extreme and polemic ideology that identifies individual liberty with private property and market rationality.

The use of the burlesque frame masks the apocalyptic character of the industrial narrative. The frame helps manage the tension between the apocalyptic narrative's implied call for radical rebellion and the neoliberal goal of restoring traditional free-market principles According to Killingsworth and Palmer, apocalyptic narrative "is an expansive and offensive rhetorical strategy." ${ }^{, 86}$ It goes on the offensive by implying "the need for radical change," by marking "oneself as an outsider," risking "alienation," and urging "others into the open air of rebellion. ${ }^{, 86}$ By deploying apocalyptic narratives, the coal industry is able to go on the offensive, position itself as a radical outsider, and call for rebellion against a caricatured opponent.

But in combination with the burlesque frame, industrial apocalyptic turns away from calls for radical social or ideological change and thus avoids risking alienation. In this sense, industrial apocalyptic is a new twist on the strategy of aggressive mimicry that Jennifer Peeples observed in the rhetoric of the Wise Use Movement, ${ }^{88}$ in which pro-industry organizations employed the anti-establishment identity and discourse of environmental groups in order to force environmentalists to use limited resources to defend themselves against the characterization that they were government insiders focused solely on special interests. In this case, the coal industry co-opts the apocalyptic language and appeals of environmentalists, but then uses a burlesque frame to position those who produce and benefit from an entrenched neoliberal ideology as radical outsiders being attacked by powerful and dominant foes. Just as Tea Party rhetors 
position themselves as radical outsiders, even while they defend the most basic and traditional liberal principles (individualism, liberty, private property), so too is the coal industry able to position itself as a radical agent of social change, even while it works to prevent social change.

The appearance of burlesque in industrial apocalyptic, its degree of intensity, and its potential shading into tragedy ${ }^{89}$ all may serve as indexes of neoliberal ideology, and point toward sites where neoliberalism's footing is not yet secure. In other words, industrial apocalyptic marks key moments of the ideological suturing of neoliberalism's contradictions. The burlesque frame is just one rhetorical tactic for pursuing this work. The exaggerated, absurd extremes of industry rhetoric analyzed in this essay mark an aggressive mode of neoliberal rhetoric, whereas the rhetoric of coal front groups that makes support for coal inherent to regional cultural values or national identity reveals its more positive, celebratory mode. Ultimately, industrial apocalyptic rhetoric attempts to clear the rhetorical field of competing voices and naturalize neoliberal ideology as the commonsense way of approaching environmental and economic crises. 


\section{Notes}

1. "If I Wanted America to Fail," YouTube video, 4:39, posted by "Free Market America," April 20, 2012,www.youtube.com/watch? $v=C Z-4 g n N z 0 v c$.

2. “Never Good Enough," Investor's Business Daily, Editorial, December 11, 2002, accessed October 4, 2013, http://news.investors.com/121102-333854-never-good-enough.htm.

3. "Ecotage," Richmond Times Dispatch, Editorial, January 23, 2001, A-10.

4. Ben Eisen, "No Reason to Fear Environmental Bogeyman; Our Children Have Been Scared into Thinking the World is Getting Worse, Evidence Suggests It's Not," Nelson Daily News, British Columbia, Editorial, July 3, 2009, 6.

5. See Judith Layzer, Open for Business: Conservatives' Opposition to Environmental Regulation (Cambridge, MA: The MIT Press, 2012). Layzer argues that opponents of neoliberal doctrine would "do well to recall — as the history recounted in this book makes clear — that much of what conservatives were saying seemed outlandish and inconceivable in the early 1970s, but in 2011 seems commonsensical” (369).

6. Samuel Hays, Beauty, Health and Permanence: Environmental Politics in the U.S. 1955-1985 (Cambridge: Cambridge University Press, 1985), 451-452.

7. M. Jimmie Killingsworth and Jacqueline S. Palmer, "The Discourse of 'Environmentalist 
Hysteria,"” Quarterly Journal of Speech 81 (1995): 11.

8. M. Jimmie Killingsworth and Jacqueline S. Palmer, "Millennial Ecology: The Apocalyptic Narrative from Silent Spring to Global Warming," in Green Culture: Environmental Rhetoric in Contemporary America, ed. Carl G. Herndl and Stuart C. Brown (Madison: University of Wisconsin Press, 1996), 21.

9. Killingsworth and Palmer, "Millenial Ecology," 35-37.

10. Christina. R. Foust and William O. Murphy, "Revealing and Reframing Apocalyptic Tragedy in Global Warming Discourse, Environmental Communication: A Journal of Nature and Culture 3 (2009): 151-167.

11. Kurt Ritter and David Henry, Ronald Reagan: The Great Communicator (Westport, CT: Greenwood, 1992); James Arnt Aune, Selling the Free Market: The Rhetoric of Economic Correctness (New York: Guilford Press, 2001).

12. Kenneth Burke, Attitudes Toward History (Berkeley: University of California Press, 1984).

13. See Angela L. Apple and Beth A. Messner, "Paranoia and Paradox: The Apocalyptic Rhetoric of Christian Identity," Western Journal of Communication 65 (2001): 206-227; Barry Brummett, Contemporary Apocalyptic Rhetoric (Westport, CT: Praeger, 1992); James Darsey, The Prophetic Tradition and Radical Rhetoric in America (New York: New York University 
Press, 1997); Joshua Gunn and David Beard, “On the Apocalyptic Sublime,” Southern Communication Journal 65 (2000): 269-286; Killingsworth and Palmer, "Millenial Ecology;" Star Muir, "Cultural and Critical Grammars of Apocalypse: Strategies for a New Millennium," in Proceedings of the Fourth Biennial Conference on Communication and Environment, ed. Susan L. Senecah (Syracuse: NY: SUNY College of Environmental Science and Forestry, 1997), 28-36; Stephen O’Leary, “A Dramatistic Theory of Apocalyptic Rhetoric,” Quarterly Journal of Speech 79 (1993): 385-426; and Ritter and Henry, Ronald Reagan.

14. Foust and Murphy, "Revealing and Reframing Apocalyptic Tragedy," 152, 153.

15. O’Leary, “A Dramatistic Theory,” 385.

16. Killingsworth and Palmer, "Millenial Ecology," 41.

17. See Brummett, Contemporary Apocalyptic Rhetoric, and Frederick Buell, From Apocalypse to Way of Life (New York: Routledge, 2003).

18. O’Leary, "A Dramatistic Theory."

19. Killingsworth and Palmer, "Millenial Ecology."

20. Kirkpatrick Sale, The Green Revolution: The American Environmental Movement $1962-$ 1992 (New York: Hill and Wang, 1993). 
21. Rachel Carson, Silent Spring (Greenwich, CT: Fawcett, 1962); Paul R. Ehrlich, The Population Bomb (New York: Ballantine, 1968).

22. Killingsworth and Palmer, "Millenial Ecology," 37.

23. Killingsworth and Palmer, "Millenial Ecology;" see also Thomas Rosteck and Thomas S. Frentz, "Myth and Multiple Readings in Environmental Rhetoric: The Case of An Inconvenient Truth," Quarterly Journal of Speech 95 (2009): 1-17; and Phillipa Spoel, David Goforth, Hoi Cheu and David Pearson, "Public Communication of Climate Change Science: Engaging Citizens through Apocalyptic Narrative Experiences, Technical Communication Quarterly 18 (2009): 49-81.

24. Judith Hendry, "Public Discourse and the Rhetorical Construction of the Technospecter," Environmental Communication: A Journal of Nature and Culture 2 (2008): 302-319;

Saffron O’Neill and Sophie Nicholson-Cole, “Fear Won’t Do It: Promoting Positive Engagement with Climate Change through Imagery and Icons, Science Communication 30 (2009): 355 379; Michael Salvador and Todd Norton, "The Flood Myth in the Age of Global Climate Change," Environmental Communication: A Journal of Nature and Culture 5 (2011): 45-61.

25. Salvador and Norton, "The Flood Myth," 49.

26. O’Leary, "A Dramatistic Theory.” 
27. Foust and Murphy, "Revealing and Reframing Apocalyptic Tragedy," 152.

28. Foust and Murphy, "Revealing and Reframing Apocalyptic Tragedy," 162.

29. Foust and Murphy, "Revealing and Reframing Apocalyptic Tragedy," 162-3.

30. Burke, Attitudes Towards History, 55.

31. Mark P. Moore, "I, Me, Mine: On the Rhetoric of Water Wars in the Pacific Northwest," in Environmental Communication Yearbook, Vol. 3, ed. Stephen Depoe (Mahwah, NJ: Lawrence Erlbaum Associates, 2006), 3.

32. Edward C. Appel, "Rush to Judgment: Burlesque, Tragedy, and Hierarchical Alchemy in the Rhetoric of America's Favorite Talk Show Host, Southern Communication Journal 68 (2003): 222.

33. Denise Bostdorff, "Making Light of James Watt: A Burkean Approach to the Form and Attitude of Political Cartoons, Quarterly Journal of Speech 73 (1987): 46.

34. Gary S. Selby, "Scoffing at the Enemy: The Burlesque Frame in the Rhetoric of Ralph David Abernathy, Southern Communication Journal 70 (2005): 136. 
35. A. Cheree Carlson, "Limitations on the Comic Frame: Some Witty American Women of the Nineteenth Century," Quarterly Journal of Speech 74 (1988): 317.

36. See respectively Moore, "I, Me, Mine;" Bostdorff, "Making Light of James Watt;" and Anne Marie Todd, "Prime-Time Subversion: The Environmental Rhetoric of The Simpsons," in Enviropop: Studies in Environmental Rhetoric and Popular Culture, ed. Mark Meister and Phyllis M. Japp (Westport, CT: Praeger, 2000), 62-80.

37. Moore, "I, Me, Mine," 14. Emphasis added.

38. Chris Smith and Ben Voth, "The Role of Humor in Political Argument: How 'Strategery' and 'Lockboxes' Changed a Political Campaign,' Argument and Advocacy 39 (2002): $111,113$.

39. Appel, "Rush to Judgment," 220.

40. Edward C. Appel, "Burlesque Drama as a Rhetorical Genre: The Hudibrastic Ridicule of William F. Buckley, Jr.,” Western Journal of Communication 60 (1996): 272.

41. Appel, "Rush to Judgment," 224. See also Burke, Attitudes Towards History, 93.

42. Appel, "Rush to Judgment," 227. 
43. Robert J. Antonio and Robert J. Brulle, “The Unbearable Lightness of Politics: Climate Change Denial and Political Polarization,” Sociological Quarterly 52 (2011): 196.

44. Antonio and Brulle, “The Unbearable Lightness of Politics,” 197.

45. Short-Term Energy Outlook, Energy Information Administration, 2012, accessed June 3, 2012, http://www.eia.gov/forecasts/steo/pdf/steo_full.pdf.

46. See Jonathan Thompson, "King Coal is Still King; Peabody Energy Will Cut 1,000 jobs, but it is Not Because of Hard Times," High Country News, November 7, 2012, accessed October 4, 2013, http://www.hcn.org/blogs/goat/king-coal-is-still-king. Thompson questions whether coal companies are under the political and economic pressure they contend. In response to Peabody Coal's announcement that it is laying off 1000 workers in the United States and Australia, Thompson writes, "Peabody, it turns out, is not hurting at all. In fact, the same story about the layoffs notes that its earnings during the third quarter of this year were higher than last year. Peabody has thrived during the alleged war waged by the Obama administration. It's had higher profits for each of the last four years than it did in 2007." The legitimacy of the "catastrophe" may or may not play into the coal companies' construction of apocalyptic appeals.

47. Eric Lipton and Clifford Krauss, "Fossil Fuel Ads Dominate TV in Campaign," New York Times, September 4, 2012, http://www.nytimes.com/2012/09/14/us/politics/fossil-fuel-industryopens-wallet-to-defeat-obama.html?pagewanted $=a l l \& \_r=0($ accessed October 4, 2013). 
48. "Coal Mining," OpenSecrets.Org, http://www.opensecrets.org/industries/indus.php?cycle $=2012 \&$ ind $=E 1210$ (accessed October 4, 2013).

49. Terence Check, "Condemning a corporation: Exxon as scapegoat," Proceedings of the Fourth Biennial Conference on Communication and Environment, ed. Susan L. Senecah (Syracuse: NY: SUNY College of Environmental Science and Forestry, 1997), 133-144; and Emily Plec and Mary Pettenger, "Greenwashing Consumption: The Didactic Framing of ExxonMobil's Energy Solutions," Environmental Communication: A Journal of Nature and Culture 6 (2012): 459-476.

50. Karl R. Smerecnik and Valerie R. Renegar, "Capitalistic Agency: The Rhetoric of BP's Helios Power Campaign," Environmental Communication: A Journal of Nature and Culture 4 (2010): 152-171.

51. "Big Coal: Decades of Deception," Greenpeace, http://quitcoal.org/coalads (accessed October 4, 2013).

52. America's Power is the website for the organization America's Power Army. The group was previously named Americans for Balanced Energy Choices (ABEC), which in 2008 became the American Coalition for Clean Coal Energy (ACCCE). 
53. "Videos," Faces of Coal, http://www.facesofcoal.org/index.php?videos (accessed October 4, 2013).

54. Advertisement from the Kansas City Star, November 5, 2007, http://www.documentcloud.org/documents/402726-2007-11-5-kansas-city-starwhymensmiling.html (accessed October 4, 2013).

55. As quoted in James Carlson, "Pro-Coal Ad Has a National Stage," Topeka Capital-Journal, November 7, 2007, http://cjonline.com/stories/110707/sta_215603726.shtml (accessed October 4, 2013).

56. The ad caught the attention of Senator John McCain, who used the images of the same three national leaders in his presidential campaign to "illustrate the fragility of our independence on foreign oil and how these people control a large part of the world's oil supply, and how important it is for us to achieve energy independence." As quoted in Carlson, "Pro-Coal Ad," A1.

57. Mark Levin, Liberty and Tyranny: A Conservative Manifesto (New York: Threshold Editions, 2009), and Brian Sussman, Eco-Tyranny: How the Left's Green Agenda will Dismantle America (Washington, D.C.: WND Books, 2012).

58. Ritter and Henry, Ronald Reagan.

59. Levin, Liberty and Tyranny, 153. 
60. Levin, Liberty and Tyranny, 134.

61. David Kinkela, DDT and the American Century: Global Health, Environmental Politics, and the Pesticide That Changed the World (Chapel Hill: University of North Carolina Press, 2013), 123.

62. “The Desolate Year,” Monsanto Magazine, October 1962, 7.

63. "The Desolate Year," 5.

64. Free Market America, "If I Wanted America to Fail," April 15, 2012, http://www.freemarketamerica.org/free-market-flashpoints/if-i-wanted-america-to-fail.html (accessed October 14, 2013). The site's description of the video as "based on Paul Harvey's seminal essay, 'If I Were the Devil'" reinforces our interpretation of the text as a secularized update of religiously inspired apocalyptic rhetoric.

65. Steve Schwarze, "Environmental Communication as a Discipline of Crisis, Environmental Communication: A Journal of Nature and Culture 1 (2007): 94.

66. Killingsworth and Palmer, "Millenial Ecology," 35.

67. Killingsworth and Palmer, "Millenial Ecology," 41. 
68. Foust and Murphy, "Revealing and Reframing Apocalyptic Tragedy."

69. Aune, Selling the Free Market, 124.

70. Moore, “I, Me, Mine,” 4.

71. This is a central argument among sympathetic critics of environmentalism; see Jonathan Porritt, Capitalism as if the World Matters (London: Routledge, 2007) and Michael Shellenberger and Ted Nordhaus, "The Death of Environmentalism: Global Warming Politics in a Post-Environmental World," January 14, 2005, http://grist.org/article/doe-reprint/ (accessed October 4, 2013).

72. Appel, "Rush to Judgment," 222.

73. Bostdorff, "Making Light of James Watt," 46.

74. Selby, "Scoffing at the Enemy," 136.

75. See Jennifer A. Peeples, "Aggressive Mimicry: The Rhetoric of Wise Use and the Environmental Movement," in the Environmental Communication Yearbook, Vol. 2, ed. Susan L. Senecah (Mahwah, NJ: Lawrence Erlbaum Associates, 2005), 1-17. 
76. Albert O. Hirschman, The Rhetoric of Reaction: Perversity, Futility, Jeopardy (Cambridge, MA: Harvard University Press, 1991).

77. Hirschman, The Rhetoric of Reaction, 127.

78. O'Leary, “A Dramatistic Theory,” 385.

79. Mathew B. Gross and Mel Gilles, The Last Myth: What the Rise of Apocalyptic Thinking Tells Us about America (Amherst, NY: Prometheus Books, 2012), 14.

80. Two days after the 2012 election, Murray Energy Corporation laid off 102 coal miners in anticipation of closing a mine in Ohio and issued a public statement blaming the layoffs on Obama's "war on coal." "Both Mr. Obama and Vice President Joe Biden stated that there would be 'no coal in America' prior to their elections. They are making good on their intentions while they destroy so many lives and family livelihoods in this area for no benefit whatsoever," said Stanley T. Piasecki, general manager and superintendent for OhioAmerican. By January 2013, the company was rehiring workers. See Alec MacGillis, "Is Obama's Coal Country Nemesis Hiring Again?" The New Republic, January 24, 2013, http://www.newrepublic.com/blog/plank/112149/obamas-coal-country-nemesis-hiring-again\# (accessed October 4, 2013).

81. Muir, "Cultural and Critical Grammars of Apocalypse." 
82. Hays, Beauty, Health, and Permanence.

83. Burke, Attitudes Towards History, 55.

84. Burke, Attitudes Towards History, 56.

85. Burke, Attitudes Towards History, 56.

86. Killingsworth and Palmer, "Millenial Ecology," 41.

87. Killingsworth and Palmer, "Millenial Ecology," 41.

88. Peeples, "Aggressive Mimicry."

89. Appel, "Rush to Judgment." 